\title{
The Effects of Solar Irradiation on Copper Speciation and Organic Complexation
}

\author{
Alessandra E. Tonietto, ${ }^{* a}$ Ana Teresa Lombardi ${ }^{a, b}$ and Armando A. H. Vieira ${ }^{b}$ \\ ${ }^{a} P P G Q$, Departamento de Química and ${ }^{b}$ Departamento de Botânica, Universidade Federal de \\ São Carlos, Rodovia Washington Luis km 235, CP 676, 13565-905 São Carlos-SP, Brazil
}

\begin{abstract}
Este trabalho teve como objetivo avaliar o efeito da irradiação solar na especiação do cobre em amostras de água coletadas em um reservatório eutrofizado e contaminado por metais. Voltametria de redissolução anódica e eletrodo de íon seletivo foram utilizados para determinação de cobre nas amostras irradiadas e não irradiadas. Os resultados demonstraram que após 7 h de irradiação solar, a matéria orgânica dissolvida (DOM) foi degradada promovendo aumento de cobre iônico livre, lábil e de carbono inorgânico dissolvido (DIC), e diminuição da concentração de ligantes disponíveis $\left(\mathrm{C}_{\mathrm{L}}\right)$ e de carbono orgânico dissolvido (DOC). Os valores da constante de estabilidade condicional (logK') variaram em duas amostras, permanecendo constantes nas demais. Os resultados demonstraram que as reações fotoquímicas afetaram a especiação do cobre e as interações Cu-DOM, ressaltando implicações ecológicas da fotoxidação, como o aumento do cobre biodisponível e, desta forma, contribuindo para o entendimento do ciclo biogeoquímico desse metal.
\end{abstract}

The aims of this research were to evaluate the effects of solar irradiation on copper speciation in water samples obtained in eutrophic and metal contaminated reservoir. Anodic stripping voltammetry and ion selective electrode were used for metal determinations of solar irradiated and non-irradiated samples. The results showed that after $7 \mathrm{~h}$ of solar irradiation, dissolved organic matter (DOM) was degraded promoting the increase of labile, free $\mathrm{Cu}^{2+}$ ions and dissolved inorganic carbon (DIC). Decreases of ligand concentration $\left(\mathrm{C}_{\mathrm{L}}\right)$ and dissolved organic carbon (DOC) were also observed. Conditional stability constant ( $\left.\log K^{\prime}\right)$ values varied for two sampling sites, but remained unchanged for the others. The present results demonstrated that photochemical reactions affected copper speciation and $\mathrm{Cu}-\mathrm{DOM}$ interactions. This research is a contribution to the understanding of biogeochemical cycle of copper and highlights some ecological implications of photooxidation in freshwater ecosystems, such as the increase of copper bioavailability.

Keywords: copper, freshwater, photooxidation, speciation, complexation

\section{Introduction}

In aquatic ecosystems, copper speciation is closely related to its uptake by the organisms. The $\mathrm{Cu}$ complexations with dissolved organic matter and inorganic ions, such as $\mathrm{Cl}^{-}, \mathrm{SO}_{4}{ }^{2-}, \mathrm{CO}_{3}{ }^{2-}$ and $\mathrm{OH}^{-}$, decrease the chemical activity of cupric ions ${ }^{1-3}$ and affect its speciation in several ways. According to Erickson et al. ${ }^{4}$ waters having much different concentrations and types of dissolved organic matter (DOM) and inorganic solutes may have the same $\mathrm{Cu}^{2+}$ concentration and same biologic effect regardless of total $\mathrm{Cu}$ concentration. Thus, the total $\mathrm{Cu}$ cannot predict $\mathrm{Cu}$ bioavailability. ${ }^{5}$ It is well established that the chemical speciation of several trace metals is controlled by the formation of organic complexes with ligands of biological origin. ${ }^{6}$

*e-mail: aletonietto@gmail.com
Natural DOM can be categorized as a complex mixture of organic compounds, each of which presenting unique elemental composition, molecular weight and a set of chemical and physical properties. ${ }^{7}$ These DOM properties can be affected by several factors, such as microbial degradation, temperature and photooxidation. ${ }^{8-10}$ The importance of each of these processes depends on the characteristics of the environment and on the DOM origin. ${ }^{3}$ Nevertheless, DOM photooxidation in natural waters, which can produce environmentally and biologically important products, may modify the physicochemical properties of the DOM. ${ }^{11}$

Because in natural environments DOM is usually present in excess concentration of trace metals, it can regulate the chemical speciation of elements such as copper, providing natural waters with the ability to accept a certain amount of total copper before the onset of toxic effects in 
the organisms. This ability is referred to as $\mathrm{Cu}$ complexation capacity $(\mathrm{Cu}-\mathrm{CC})$ and, therefore, both aqueous copper and $\mathrm{Cu}-\mathrm{CC}$ are parameters related to the health and ability of aquatic systems to endure $\mathrm{Cu}$ inputs. ${ }^{12}$

Although the photic zone is only a small fraction of surface aquatic ecosystems, this sunlit layer is very dynamic. Solar irradiation is responsible for numerous physicochemical changes, such as photodegradation, occurring in that environment, some of them irreversible. Sander et al. ${ }^{13}$ and Shank et al. ${ }^{14}$ showed a decrease of $20-90 \%$ of the strong $\mathrm{Cu}$ ligands in photooxidized DOM. Release of previously bound $\mathrm{Cu}^{2+}$ due to DOM photomineralization has been shown in Sunda and Hanson. ${ }^{15}$

When sunlight is absorbed by natural DOM, its average molecular weight is reduced and a variety of photoproducts are formed. ${ }^{16}$ Some of these are inorganic compounds such as $\mathrm{CO}, \mathrm{CO}_{2}$ and other forms of dissolved inorganic carbon. While other ones are organic molecules that, although smaller in size than their parent, remain part of the DOM pool. Thus, it is expected that a change on the chemical characteristics of the bulk DOM will be a consequence of the photochemical processes that leads to alterations related to the biological reactivity of the organic materials, as well as the involved metal ions. This research investigates the effects of sunlight irradiation on copper speciation and $\mathrm{Cu}-\mathrm{DOM}$ interactions. We determined free copper ions, total dissolved and labile copper species, as well as the association of copper with the DOM through the determination of ligand concentration and conditional stability constants.

\section{Experimental}

\section{Study area}

Water samples were obtained in August 2006 from a shallow (mean depth: $10.2 \mathrm{~m}$ ), turbulent, and hypereutrophic reservoir (Barra Bonita Reservoir, São Paulo State) located in Brazil (22 $\left.29^{\prime} \mathrm{S}, 48^{\circ} 34^{\prime} \mathrm{W}\right)$. It is formed by the confluence of two contaminated rivers that receive industrial and agricultural wastes (Figure S1). The reservoir is subject to phytoplankton blooms throughout the year, taking to high content of biological organic materials. ${ }^{17}$ Its total water volume is $3.16 \times 10^{9} \mathrm{~m}^{3}$ in an area of $324.84 \mathrm{~km}^{2}$. Surface water samples were obtained in four GPS (global positioning system) defined sampling sites as shown in Figure S1. Site 1: latitude S $22^{\circ} 36.770^{\prime}$, longitude W $48^{\circ} 20.752^{\prime}$; site 2: latitude S $22^{\circ} 33.929^{\prime}$, longitude W $48^{\circ} 24.159^{\prime}$; site 3: latitude S $22^{\circ} 32.666^{\prime}$, longitude W $48^{\circ} 29.155^{\prime}$; site 4: latitude S $22^{\circ} 31.391$ ', longitude W 48³1.868'.

\section{General procedures and instrumental analyses}

Water samples were filtered through sterile Polycap capsules with $0.22 \mu \mathrm{m}$ pore size. Filtered water was transfered to $500 \mathrm{~mL}$ capacity quartz containers and submitted to natural solar irradiation $(100-3000 \mathrm{~nm})^{18}$ for $7 \mathrm{~h}$ (in vitro experiment). Incident sunlight (Figure 1) was measured using a radiometer (QSL-100 Biospherical Instruments). Water parameters, e.g. $\mathrm{pH}$, temperature, dissolved oxigen, total dissolved solids and conductivity were measured in situ using a portable YSI (model 556MPS) equipment. Trace metal clean techniques were used for sample preparation, collection and analysis. ${ }^{19,20}$ Water samples were collected in screw capped plastic containers, stored in plastic bags, packed in ice and immediately transported to the laboratory. All plastic materials were washed with neutral detergent, further kept in $\mathrm{HNO}_{3} 0.1 \mathrm{~mol} \mathrm{~L}^{-1}$ for 7 days and finally rinsed with ultrapure water (Barnstead System). Three experimental replicates were performed.

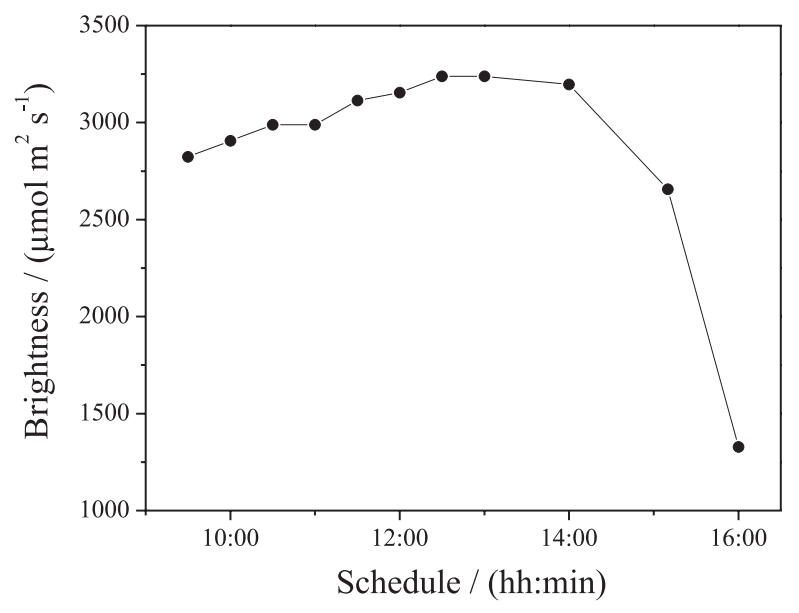

Figure 1. Solar irradiation $\left(\mu \mathrm{mol} \mathrm{m} \mathrm{m}^{2} \mathrm{~s}^{-1}\right)$ measured during sample exposure time.

Dissolved organic carbon (DOC) was determined by high temperature oxidation (TOC- $\mathrm{V}_{\mathrm{CPH}}$ Shimadzu) through the difference between total (TC) and inorganic carbon (IC). Statistical analysis of the data was performed using either student- $t$ test or ANOVA, depending on the number of samples.

\section{Procedures for the determination of studied copper speciation}

Copper speciation included the determination of total dissolved, labile and free $\mathrm{Cu}^{2+}$ ions. Total dissolved and labile copper were determined through differential pulse anodic stripping voltammetry (DPASV) and free copper ions through ion-selective electrode (ISE). Three 
replicate analyses were performed for all determinations. DPASV static mercury drop electrode (EG\&G PARC Model 303A) system connected to a potentiostat EG\&G Model 394 electrochemical trace analyzer was used. A saturated $\mathrm{Ag} / \mathrm{AgCl} / \mathrm{KCl}$ was used as reference electrode and a Pt as counter electrode. At the beginning of copper determination, the solutions were deoxygenated with high purity nitrogen for $10 \mathrm{~min}$. Further, prior to each analysis, the solution was deoxygenated for $2 \mathrm{~min}$.

For all determinations, ionic strengths were adjusted to $0.01 \mathrm{~mol} \mathrm{~L}^{-1}$ with $\mathrm{KNO}_{3}$ (Merck) as supporting electrolyte. An equilibrium time of $20 \mathrm{~min}$ for each metal addition ${ }^{21}$ was used and after this a deposition of $10 \mathrm{~min}$ at $-0.6 \mathrm{~V}$ was performed, and DPASV-labile copper concentrations were monitored as function of added copper. Based on a 1:1 complexation model, total ligand concentration $\left(\mathrm{C}_{\mathrm{L}}\right)$ and conditional stability constants $\left(\mathrm{K}^{\prime}\right)$ were calculated assuming single site model as described in Ruzic. ${ }^{22}$

For total dissolved copper determination, samples were digested using a microwave-assisted photochemical procedure following Sodré $e t$ al. ${ }^{23}$ Total dissolved copper was determined by DPASV in acidified filtrates. After purging the sample with suprapure $\mathrm{N}_{2}$, $\mathrm{Cu}$ was deposited at the $\mathrm{Hg}$ electrode using a $-0.6 \mathrm{~V}$ potential for 5 min under stirring conditions and $10 \mathrm{~s}$ rest time. Anodic scanning was performed at a scan rate of $8 \mathrm{mV} \mathrm{s}^{-1}$ and pulse height of $50 \mathrm{mV}$.

For free copper determinations, potential readings were obtained using a $\mathrm{pH} / \mathrm{ISE}$ meter (ATI ORION model 710A). The $\mathrm{Cu}$ (ATI ORION, model 94-29) electrode was used with an $\mathrm{Ag} / \mathrm{AgCl}$ double-junction reference electrode (ATI ORION, model 90-02). Free $\mathrm{Cu}^{2+}$ ions determinations were performed at constant temperature $20 \pm 1^{\circ} \mathrm{C}$ and ionic strength $\left(0.1 \mathrm{~mol} \mathrm{~L}^{-1}\right)$ adjusted with $\mathrm{NaNO}_{3}$ (MicroSelect, Fluka Chemie). Calibrations were performed using a copper standard solution $\left(1.57 \times 10^{-2} \mathrm{~mol} \mathrm{~L}^{-1}\right)$ made from $\mathrm{CuCl}_{2}$ (Titrisol, Merck) by serial dilutions. ISE calibration curves had their linearity extended up to $1.0 \times 10^{-13} \mathrm{~mol} \mathrm{~L}^{-1}$ using copper ion buffers according to Lombardi et al. ${ }^{24}$

\section{Results}

The results for water quality parameters showed that there was not a significant difference among the sampling points. Water temperature presented an average minimum value of $22.9^{\circ} \mathrm{C}$ in site 1 and maximum of $24.0^{\circ} \mathrm{C}$ in site 3 ; $\mathrm{pH}$ values ranged from 7.61 to 7.90 ; dissolved oxygen concentrations were $8.75,8.83,4.51$ and $7.67 \mathrm{mg} \mathrm{L}^{-1}$ at sites 1, 2, 3 and 4, respectively.

Significant differences before and after sample irradiation for total ligand concentration $\left(\mathrm{C}_{\mathrm{L}}\right)$, DIC and DOC were obtained. An increase of DIC and a decrease of DOC in sites $2(P<0.0001)$ and $4(P=0.0002)$, as well as a decrease of $\mathrm{C}_{\mathrm{L}}$ were observed and are shown in Table 1. The $C_{L}$ decrease was a general tendency observed for all sampling sites after solar irradiation. After approximately $7 \mathrm{~h}$ of solar irradiation, which corresponds to one day of insolation at our field station, $17.1 \% \mathrm{C}_{\mathrm{L}}$ were destroyed in samples of site $1(P<0.0001), 15.3 \%$ site 2 $(P=0.0001), 7.20 \%$ site $3(P=0.0005)$ and $27.8 \%$ in site 4 samples $(P<0.0001)$. In relation to conditional stability constant (K') values (Table 1), while stronger copperorganic complexes were present after solar irradiation in site 2 samples $(P<0.0338)$, weaker copper-organic complexes were detected in site 3 samples $(P=0.0137)$. For sites 1 and 4, K' values were considered statistically similar for non-irradiated and solar irradiated samples. Total dissolved copper concentrations varied among sampling sites $(P<0.0001)$ (Figure 2$)$. The highest total dissolved copper concentration was detected in site 1 samples $(P<0.0001)$ (Figure 2A), confirming the greater influence of industrial and urban waste. Copper speciation differed in non-irradiated and solar irradiated samples. An increase of free $\mathrm{Cu}^{2+}$ ions concentrations (Figure 2B, $2 \mathrm{C}$ and 2D) in samples of sites 2,3 and $4(P<0.0001)$ were obtained after solar irradiation. Also, labile copper concentrations were higher (Figure 2A, 2C and 2D) in sites $1(P=0.0009), 3(P<0.0001)$ and $4(P<0.0001)$ after solar irradiation.

Table 1. Ligand concentration $\left(\mathrm{C}_{\mathrm{L}}, \mathrm{nmol} \mathrm{L}^{-1}\right)$, log conditional stability constant $\left(\log \mathrm{K}^{\prime}\right)$, dissolved organic carbon (DOC, $\left.\mathrm{mg} \mathrm{L}^{-1}\right)$ and dissolved inorganic carbon (DIC, $\left.\mathrm{mg} \mathrm{L}^{-1}\right)$ concentrations quantified before $(0 \mathrm{~h})$ and after $(7 \mathrm{~h})$ solar irradiation for the four samples collected in Barra Bonita Reservoir at the respective sampling sites $(1,2,3$ and 4$)$. Values represent the mean $\pm \operatorname{SD}(n=3)$

\begin{tabular}{|c|c|c|c|c|c|c|c|c|c|c|c|c|}
\hline & \multicolumn{3}{|c|}{ Site 1} & \multicolumn{3}{|c|}{ Site 2} & \multicolumn{3}{|c|}{ Site 3} & \multicolumn{3}{|c|}{ Site 4} \\
\hline & $0 \mathrm{~h}$ & $7 \mathrm{~h}$ & $t$-test & $0 \mathrm{~h}$ & $7 \mathrm{~h}$ & $t$-test & $0 \mathrm{~h}$ & $7 \mathrm{~h}$ & $t$-test & $0 \mathrm{~h}$ & $7 \mathrm{~h}$ & $t$-test \\
\hline $\mathrm{C}_{\mathrm{L}}$ & $317.3 \pm 2.86$ & $262.9 \pm 0.55$ & $P<0.0001$ & $238.3 \pm 2.46$ & $201.9 \pm 3.25$ & $P=0.0001$ & $232.9 \pm 2.35$ & $216.2 \pm 1.42$ & $P=0.0005$ & $239.3 \pm 7.26$ & $172.8 \pm 0.54$ & $P<0.0001$ \\
\hline $\log \mathrm{K}^{\prime}$ & $8.16 \pm 0.04$ & $8.23 \pm 0.09$ & $P=0.2857$ & $7.71 \pm 0.15$ & $8.04 \pm 0.10$ & $P<0.0338$ & $8.44 \pm 0.01$ & $8.34 \pm 0.04$ & $P=0.0137$ & $8.40 \pm 0.10$ & $8.53 \pm 0.55$ & $P=0.7077$ \\
\hline DOC & $5.62 \pm 0.01$ & $5.77 \pm 0.28$ & $P=0.4063$ & $7.44 \pm 0.04$ & $6.42 \pm 0.08$ & $P<0.0001$ & $5.22 \pm 0.15$ & $5.39 \pm 0.11$ & $P=0.1886$ & $7.32 \pm 0.16$ & $6.07 \pm 0.07$ & $P=0.0002$ \\
\hline DIC & $7.98 \pm 0.28$ & $8.00 \pm 0.01$ & $P=0.9076$ & $10.2 \pm 0.01$ & $11.1 \pm 0.09$ & $P<0.0001$ & $9.38 \pm 0.05$ & $9.39 \pm 0.19$ & $P=0.9340$ & $9.10 \pm 0.07$ & $10.1 \pm 0.09$ & $P=0.0001$ \\
\hline
\end{tabular}



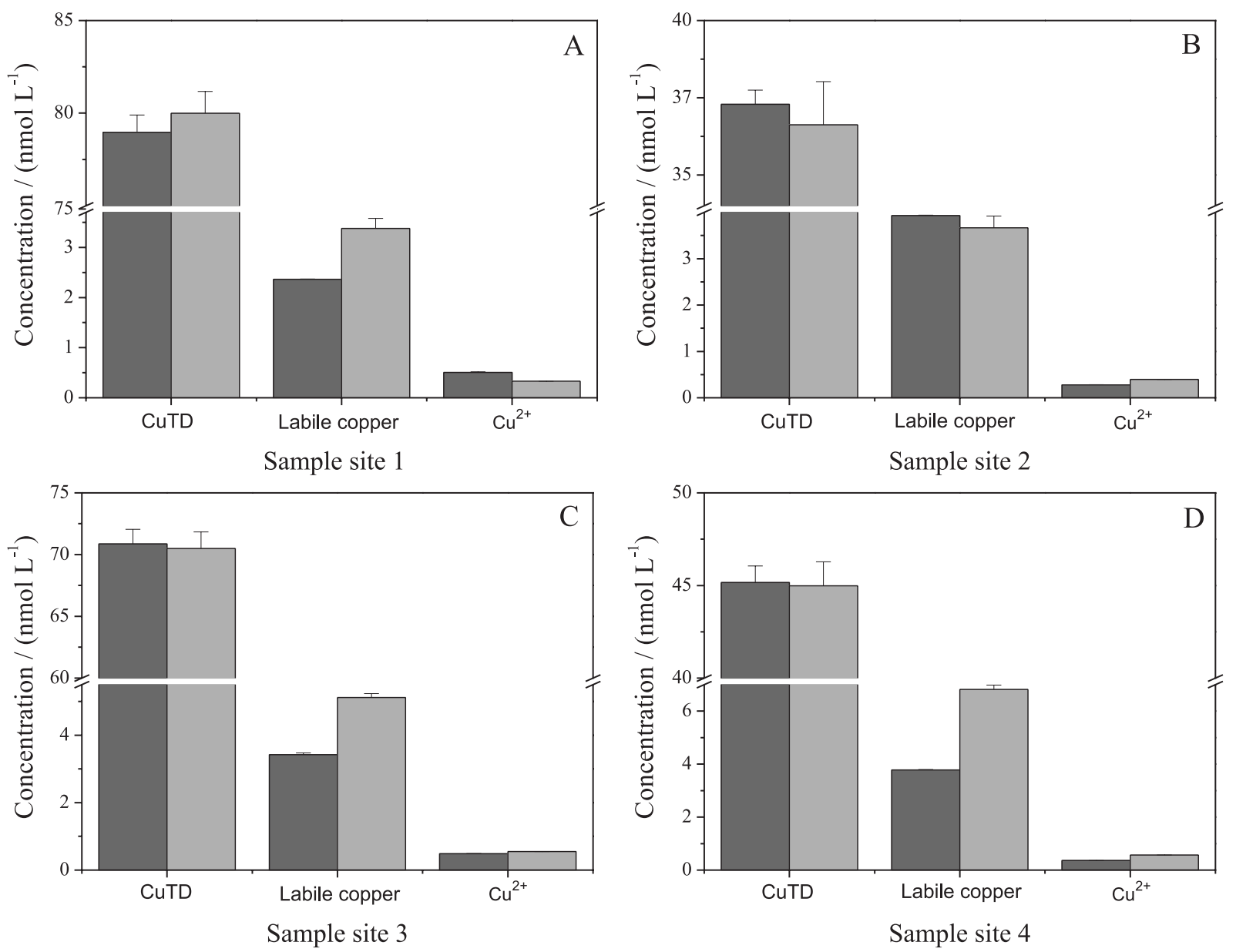

Figure 2. Total dissolved copper concentrations $(\mathrm{CuTD})\left(\mathrm{nmol} \mathrm{L}{ }^{-1}\right)$, free $\mathrm{Cu}^{2+}$ ions concentration $\left(\mathrm{nmol} \mathrm{L}^{-1}\right)$, labile copper concentration $\left(\mathrm{nmol} \mathrm{L} \mathrm{L}^{-1}\right)$ before (dark gray) and after (light gray) solar irradiation for the several samples $(n=3)$, A: site 1, B: site 2, C: site 3 and D: site 4.

\section{Discussion}

Barra Bonita Reservoir receives inorganic and organic contaminants, leading to high $\mathrm{pH}$ and conductivity values, as measured in this study. These results are in agreement with those presented by Valente et al. ${ }^{25}$ MatsumuraTundisi and Tundisi, ${ }^{26}$ Panhota et al. ${ }^{27}$ and Tundisi et al. ${ }^{28}$ which showed that such reservoir is highly eutrophic. Nevertheless, high oxygen concentrations were detected in sites 1,2 and 4. These are possibly the result of high phytoplankton photosynthetic activity during daytime, what is supported by high chlorophyll concentrations. ${ }^{17}$

Total dissolved copper was similar for solar irradiated and non-irradiated samples, as expected. However, free copper ions and labile copper significantly increased after irradiation of the samples, whereas $C_{L}$ decreased. Together, these results demonstrate that copper complexing sites were directly affected by irradiation and previously complexed copper ions were made free, thus exchanging from low bioavailable copper species to more readily available ones.
Literature data show that, in general, DOM is not only subject to photooxidation, but to all sorts of processes occurring in the natural environment, such as dissolved oxygen concentration, redox potential, $\mathrm{pH}$, temperature, ionic strength, zooplankton and phytoplankton activities, as well as heterotrophic degradation among others. Altogether these factors affect the DOM and so, the speciation of metal ions. Moreover, the relative importance of such factors is dependent on the circulation, depth and trophic state of the environment, since different processes will be taking place in the dark and in the light, with high $\mathrm{O}_{2}$ concentration during the day and low $\mathrm{O}_{2}$ during the night in hypereutrophic environments. The present research has focused on one of the mentioned factors only, photooxidation of the DOM induced by sunlight and how this can possibly affect metal speciation. Because we have focused on one aspect of the several that may occur in the in situ situation, we have also focused and restricted our discussion to the aspect we have investigated ex situ. Overall, we demonstrated that photochemical process is an important factor that affects metal speciation and, although all our experiments 
were performed ex situ, the results support that similar effects occur in the natural environment, which is subject to sunlight irradiation.

The decrease of $C_{L}$ were obtained after solar irradiation and is in accordance to the results presented by Shank et al.,${ }^{14}$ who showed that exposure to solar irradiation decreased the complexing capacity of water samples obtained at the organic-rich Cape Fear Estuary (in U. S. A.). The authors detected a $15-33 \%$ loss of strong $\mathrm{Cu}$ complexing ligands in 24-48 h sunlight exposure and $90 \%$ loss on longer-term exposures. Brinkmann et al. ${ }^{29}$ showed that dissolved organic matter is a highly dynamic component of natural waters and photodegradation by sunlight is an important factor contributing to its changes. DOM photoreactivity can result in its mineralization, as well as in a significant decrease of the average molecular weight of the remaining DOM. Conditional stability constants ( $\left.\log \mathrm{K}^{\prime}\right)$ inform about the strength of complexation with available sites in a sample. The similarity among the K' values obtained in this study before and after solar irradiation suggests that important copper associations (e.g., those with strong complexing properties that can have significant effect during the titration process) were not affected by solar irradiation. Linking these results with the reduction of available ligands $\left(\mathrm{C}_{\mathrm{L}}\right)$ in the irradiated samples, one can rationale that copper had been complexed to inorganic and weak organic ligand. These results are in agreement with those presented by Sander et al. ${ }^{13}$ who showed a reduction of ligand concentration $\left(\mathrm{C}_{\mathrm{L}}\right)$ and complexed copper after irradiation of DOM rich water samples. Also supporting our hypothesis of inorganic ligands and weak organic ligands modification as a consequence of sunlight irradiation, Shiller et al..$^{30}$ proposed that photo-induced changes in high strength organic ligands occur upon longer periods of exposure, not short periods, as used in the present research. Nevertheless, Moran and Zepp ${ }^{31}$ reported that photochemical processes can change the chemical characteristics of DOM, and consequently, its biological reactivity.

An exception to the $K$ ' value is related to site 2 samples, which increased after solar irradiation. The increase in the strength of association between copper and the ligands present can be due to conformational changes in the DOM. In fact, literature data show that sunlight irradiation can mediate chemical changes in the DOM, which can lead to the exposure of previous complexing inactive sites, as proposed by Patel-Sorrentino et al. ${ }^{32}$

\section{Conclusions}

Based on our findings, we conclude that sunlight exposure can cause substantial changes in copper speciation in aquatic ecosystems, affecting the interactions of metal ions with the ligands present. In addition, we suggest that inorganic ligands and weak organic ligands are the first to be affected by the irradiation, immediately followed by DOC reduction. Thus, current increases in UV radiation due to loss of stratospheric ozone ${ }^{33}$ may have significant impact for the aquatic biota. Ecological implications resulting from the increase of the labile and free copper ions, which can have food web consequences, should be considered. The present study demonstrated that $7 \mathrm{~h}$ of continuous sunlight exposure in a subtropical area oxidizes some of the organic and inorganic carbon, and this significantly affected copper speciation and water complexing capacity.

\section{Supplementary Information}

Supplementary information (Figure S1) is available free of charge at http://jbcs.org.br as a PDF file.

\section{Acknowledgments}

We thank Fundação de Amparo à Pesquisa do Estado de São Paulo (FAPESP processes 2005/51263-5 and 2008/03487-0) and Conselho Nacional de Desenvolvimento Científico e Tecnológico (CNPq processes 472509/2006-3 and 556588/2009-6) for financial support. A. E. T. thanks Coordenação de Aperfeiçoamento de Pessoal de Nível Superior (CAPES) for a scholarship.

\section{References}

1. Templeton, D. M.; Ariese, F.; Cornelis, R.; Danielsson, L. G.; Muntau, H.; Van Leeuwen, H. P.; Lobinski, R.; Pure Appl. Chem. 2000, 72, 1453.

2. Averyt, K. B.; Kim, J. P.; Hunter, K. A.; Limnol. Oceanogr. 2004, 49, 20.

3. Brooks, M. L.; Meyer, J. S.; McKnight, D. M.; Hydrobiologia 2007, 579, 95.

4. Erickson, R. J.; Benoit, D. A.; Mattson, V. R.; Nelson Jr., H. P.; Leonard, E. N.; Environ. Toxicol. Chem. 1996, 15, 181.

5. Luoma, S. N.; Sci. Total Environ. 1983, $28,1$.

6. Bruland, K. W.; Donat, J. R.; Hutchins, D. A.; Limnol. Oceanogr. 1991, 36, 1555.

7. Perdue, E. M.; Ritchie, J. D. In Surface and Ground Water, Weathering, Erosion and Soils; Drever, J. I., ed.; ElsevierPergamon: Oxford, 2003.

8. Dehaan, H.; Limnol. Oceanogr. 1993, 38, 1072.

9. Bourbonniere, R. A.; Miller, W. L.; Zepp, R. G.; J. Geophys. Res.-Atmos. 1997, 102, 29321.

10. Molot, L. A.; Dillon, P. J.; Global Biogeochem. Cycles 1997, 11,357 . 
11. Lou, T.; Huixiang, X.; Chemosphere 2006, 65, 2333.

12. Rivera-Duarte, I.; Zirino, A.; Environ. Sci. Technol. 2004, 38, 3139.

13. Sander, S.; Kima, J. P.; Anderson, B.; Hunter, K. A.; Environ. Chem. 2005, 2, 56.

14. Shank, G. C.; Whitehead, R. F.; Smith, M. L.; Skrabal, S. A.; Kieber, R. J.; Limnol. Oceanogr. 2006, 51, 884.

15. Sunda, W. G.; Hanson, P. J. In Chemical Modelling in Aquatic Systems; Jenne, E. A., ed.; American Chemical Society: Florida, 1979.

16. Zepp, R. G.; Callaghan, T.; Erickson, D.; Ambio 1995, 24, 181.

17. Vieira, A. A. H.; Ortolano, P. I. C.; Giroldo, D.; Oliveira, M. J. D.; Bittar, T. B.; Lombardi, A. T.; Sartori, A. L.; Limnol. Oceanogr. 2008, 53, 1887.

18. Sigee, D. C.; Freshwater Microbiology: Biodiversity and Dynamic Interactions of Microorganisms in the Freshwater Environment; John Wiley \& Sons Ltd: England, 2005.

19. United States Environmental Protection Agency (US-EPA); Method 1669 - Sampling Ambient Water for Determination of Trace Metals at EPA Water Quality Criteria Level, Washington DC, USA, 1996.

20. Campos, M. L. A. M.; Bendo, A.; Viel, F. C.; Quim. Nova 2002, 25, 808 .

21. Mylon, S. E.; Twining, B. S.; Fisher, N. S.; Benoit, G.; Environ. Sci. Technol. 2003, 37, 1261.

22. Ruzic, I.; Anal. Chim. Acta 1982, 140, 99.
23. Sodre, F. F.; Peralta-Zamora, P. G.; Grassi, M. T.; Quim. Nova 2004, 27, 695.

24. Lombardi, A. T.; Hidalgo, T. M. D.; Vieira, A. A. H.; Sartori, A. L.; Phycologia 2007, 46, 74.

25. Valente, J. P. S.; Padilha, P. M.; Silva, A. M. M.; Eclet. Quim. 1997, 22, 31 .

26. Matsumura-Tundisi, T.; Tundisi, J. G.; Hydrobiologia 2005, 542, 367.

27. Panhota, R. S.; Bianchini, I.; Vieira, A. A. H.; Hydrobiologia 2007, 583, 223.

28. Tundisi, J. G.; Matsumura-Tundisi, T.; Abe, D. S.; Braz. J. Biol. 2008, 68, 1079.

29. Brinkmann, T.; Horsch, P.; Sartorius, D.; Frimmel, F. H.; Environ. Sci. Technol. 2003, 37, 4190.

30. Shiller, A. M.; Duan, S. W.; Van Erp, P.; Bianchi, T. S.; Limnol. Oceanogr. 2006, 51, 1716.

31. Moran, M. A.; Zepp, R. G.; Limnol. Oceanogr. 1997, 42, 1307.

32. Patel-Sorrentino, N.; Mounier, S.; Lucas, Y.; Benaim, J. Y.; Sci. Total Environ. 2004, 321, 231.

33. McKenzie, R.; Conner, B.; Bodeker, G.; Science 1999, 285, 1709.

Submitted: October 25, 2010

Published online: June 14, 2011

FAPESP has sponsored the publication of this article. 
The Effects of Solar Irradiation on Copper Speciation and Organic Complexation

Alessandra E. Tonietto, ${ }^{* a}$ Ana Teresa Lombardi ${ }^{a, b}$ and Armando A. H. Vieira ${ }^{b}$

${ }^{a} P P G Q$, Departamento de Química and ${ }^{b}$ Departamento de Botânica, Universidade Federal de

São Carlos, Rodovia Washington Luis km 235, CP 676, 13565-905 São Carlos-SP, Brazil

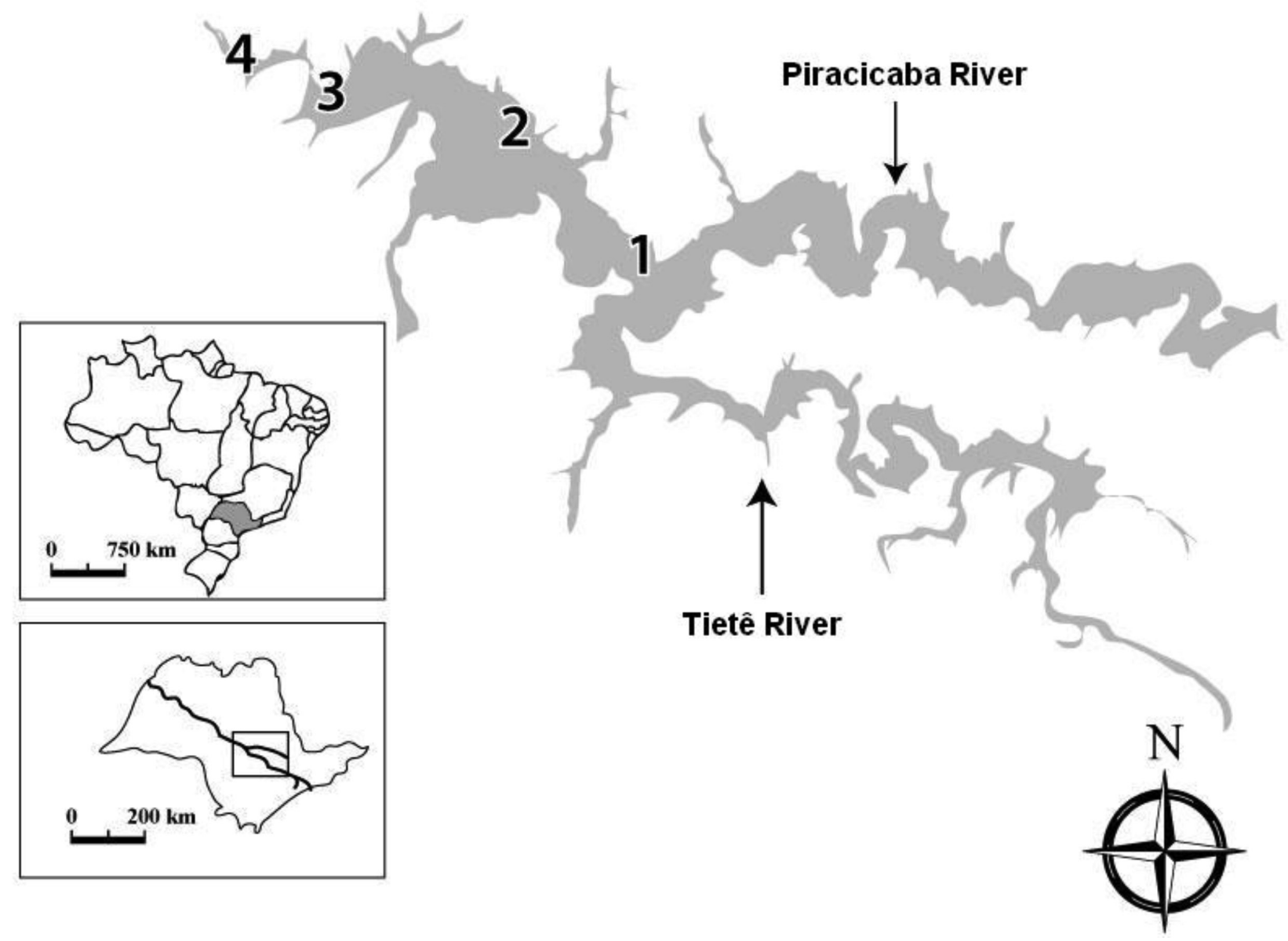

Figure S1. Map of study area showing sampling sites 1,2, 3 and 4. 